\title{
Activity of biochemical biomarkers in grasshoppers Abracris flavolineata (De Geer,
} 1773) (Orthoptera: Acrididae: Ommatolampidinae)

\author{
Atividade de biomarcadores bioquimicos em gafanhotos Abracris flavolineata (De Geer, 1773) \\ (Orthoptera: Acrididae: Ommatolampidinae)
}

Actividad de los biomarcadores bioquímicos en saltamontes Abracris flavolineata (De Geer, 1773)

(Orthoptera: Acrididae: Ommatolampidinae)

Received: 08/26/2021 | Reviewed: 09/01/2021 | Accept: 09/01/2021 | Published: 09/05/2021

\author{
Ana Catia Santos da Silva \\ ORCID: https://orcid.org/0000-0001-9474-9693 \\ Universidade Federal do Recôncavo da Bahia, Brazil \\ E-mail: anacatiabio@gmail.com \\ Aline Santos dos Santos \\ ORCID: https://orcid.org/0000-0001-8577-9321 \\ Universidade Federal do Recôncavo da Bahia, Brazil \\ E-mail: aline.santos58@yahoo.com.br \\ Theila dos Santos Santana \\ ORCID: https://orcid.org/0000-0001-7093-2565 \\ Universidade Federal do Recôncavo da Bahia, Brazil \\ E-mail: theilaribeirosantana@gmail.com \\ Elissandra Ulbricht Winkaler \\ ORCID: https://orcid.org/0000-0003-3297-4283 \\ Universidade Federal do Recôncavo da Bahia, Brazil \\ E-mail: elis@ufrb.edu.br \\ Marcos Gonçalves Lhano \\ ORCID: https://orcid.org/0000-0002-2760-5718 \\ Universidade Federal de São Carlos, Brazil \\ E-mail: marcosgl@ufscar.br
}

\begin{abstract}
Biochemical biomarkers are commonly used in environmental monitoring programs due to their sensitivity to certain pollutants. From this perspective, their responses can be used as indicators of environmental quality. The present study aimed to determine the activity of the catalase (CAT) and glutathione- $S$-transferase (GST) enzymes in grasshoppers Abracris flavolineata (De Geer, 1773) from two forest remnant areas in Serra da Jiboia (BA) and compare them between males and females. The specimens were collected at two sites in Serra da Jiboia (Bahia, Brasil), named 'Baixa de Areia' and 'Baixa Grande'. The animals were actively collected in the morning using a sweep net and a $2.5 \mathrm{~h}$ sampling effort. In total, 160 individuals were collected, with 80 individuals from each sampling site, 50 males and 30 females. After identification, an incision was made in the lateral region of the abdomen to remove the midgut, which was used to extract the CAT and GST enzymes. The results obtained demonstrated that CAT and GST activity did not vary significantly between sampling areas. However, with regard to sex, enzyme activity was significantly higher in males $(\mathrm{p}<0.005)$ in both locations. This is a pioneer study on the responses of CAT and GST activity in grasshoppers in Brazil.
\end{abstract}

Keywords: Enzyme; Oxidative estress; Glutathiona S-transferase; Catalase.

\section{Resumo}

Os biomarcadores bioquímicos são comumente usados em programas de monitoramento ambiental por serem sensíveis à presença de determinados poluentes. Assim, a resposta desse biomarcadores pode ser utilizada como um indicador de qualidade ambiental. O presente estudo teve como objetivos determinar a atividade das enzimas catalase (CAT) e glutationa-S-transferase (GST) de gafanhotos Abracris flavolineata (De Geer, 1773), coletados em área duas áreas de remanescente florestal na Serra da Jiboia (BA) e comparar a atividade destas enzimas entre machos e fêmeas. As coletas dos espécimes foram realizadas em dois pontos situados na Serra da Jiboia (Bahia, Brasil), denominados 'Baixa de Areia' e 'Baixa Grande'. Os insetos foram capturados por meio de busca ativa com auxílio de rede entomológica, no período matutino, e esforço de coleta com $2,5 \mathrm{~h}$ de duração. No total, foram coletados 160 indivíduos, sendo 80 exemplares provenientes de cada ponto amostral, com 50 machos e 30 fêmeas. Após a identificação procedeu-se incisão na região lateral do abdômen para retirada do intestino médio, que foi utilizado para 
extração das enzimas CAT e GST. Os resultados obtidos demonstraram que a atividade da CAT e GST não variou significativamente entre os pontos de coletas, entretanto, em relação ao sexo, a atividade das enzimas foi significativamente maior nos machos $(\mathrm{p}<0,005)$, em ambos os pontos amostrados. Este estudo é pioneiro na avaliação das respostas da atividade da CAT e GST em gafanhotos no Brasil.

Palavras-chave: Enzima; Estresse oxidativo; Glutathiona S-transferase; Catalase.

\section{Resumen}

Se utilizan comúnmente biomarcadores bioquímicos en programas de monitoreo ambiental pues son sensibles a la presencia de ciertos contaminantes. Por lo tanto, la respuesta de estos biomarcadores se puede utilizar como indicador de la calidad ambiental. El presente estudio tuvo como objetivo determinar la actividad de las enzimas catalasa (CAT) y glutatión-S-transferasa (GST) del saltamontes Abracris flavolineata (De Geer, 1773) recolectados en dos áreas de remanentes forestales en la Serra da Jiboia (BA) y comparar la actividad de estas enzimas entre machos y hembras. Los ejemplares se recogieron en dos puntos ubicados en la Serra da Jiboia (Bahía, Brasil), denominados 'Baixa de Areia' y 'Baixa Grande'. Los insectos fueron capturados a través de la búsqueda activa con la ayuda de una red entomológica, por la mañana, y un esfuerzo de recolección de 2,5 horas de duración. Se recolectaron 160 individuos en lo total, con 80 ejemplares de cada punto de muestreo, siendo 50 machos y 30 hembras. Después de la identificación, se realizó una incisión en la región lateral del abdomen para extirpar el intestino medio, que se utilizó para extraer las enzimas CAT y GST. Los resultados obtenidos demostraron que la actividad de CAT y de GST no varió significativamente entre los puntos de muestreo, sin embargo, en relación al sexo, la actividad enzimática fue significativamente mayor en los machos $(\mathrm{p}<0,005)$, en ambos puntos muestreados. Este estudio es pionero en la evaluación de las respuestas de la actividad de las enzimas CAT y GST en saltamontes de Brasil.

Palabras clave: Enzima; Estrés oxidativo; Glutatión S-transferasa; Catalasa.

\section{Introduction}

Invertebrates are important ecosystem components, and several taxa are often used for environmental biomonitoring purposes (Hsu et al., 2006; Zaoralova et al., 2020). From this perspective, insects are prone to normal levels of oxidative stress imposed by their aerobic lifestyle (Barbehenn, 2003).

In herbivorous insects, the situation is exacerbated due to the ingestion of pro-oxidant allelochemicals, which are eliminated at the cost of increased oxidative stress (Felton \& Summers, 1995). Such as other eukaryotes, insects have a set of antioxidant enzyme systems that protect their cells from the harmful effects of oxidative radicals (Ahmad, 1992), including Reactive Oxygen Species (ROS). ROS are mainly produced by the incomplete reduction of $\mathrm{O}_{2}$ and may cause lipid peroxidation of membranes and direct damage to biomolecules, affecting cellular metabolic processes (Paital, 2018). Thus, all organisms have an antioxidant defense system formed by enzymes responsible for neutralizing excess ROS. Therefore, the analysis of the activity of these enzymes can indicate the antioxidant status of organisms, serving as a potential biochemical biomarker of oxidative stress (Valavanidis et al., 2006).

Several biomarker enzymes can be used to assess oxidative stress in animals. From this perspective, catalase (CAT) is an antioxidant enzyme that acts against ROS by converting $\mathrm{H}_{2} \mathrm{O}_{2}$ to $\mathrm{H}_{2} \mathrm{O}$ and $\mathrm{O}_{2}$ and is mainly involved in the reduction of $\mathrm{H}_{2} \mathrm{O}_{2}$ produced by the long-chain fatty acid metabolism in peroxisomes (Birben et al., 2012; Afiyanti \& Chen, 2014; Pierezan et al. 2017). Likewise, the enzyme glutathione $S$-transferase (GST) is a biochemical marker involved in the cellular detoxification of electrophilic compounds that highlights early signs of stress caused by pollutants (Lushchak, 2011; Board \& Menon, 2013).

The activity of CAT and GST enzymes were considered good biomarkers of aquatic contamination in freshwater shrimp Macrobrachium jelskii (Miers, 1877) exposed to water from urban and rural (Mota et al., 2021). In grasshoppers, as in other insects, the activity of enzymes such as CAT and GST can be increased when exposed to some stressor (Kafel et al., 2014). From this perspective, many studies have demonstrated that these enzymes vary as a function of sex and the level of environmental contamination, as observed by Zhang et al. (2011) when studying Oxya chinensis (Thunberg, 1815) (Orthoptera: Acrididae: Oxyinae), and by Augustyniak et al. (2014) in Chorthippus brunneus (Thunberg, 1815) (Orthoptera: Acrididae: Gomphocerinae). Likewise, Wang et al. 2020 observed that the activity of the CAT and GST enzymes in 
grasshoppers Calliptamus abbreviatus Ikonnikov, 1913 (Acrididae) was significantly increased when exposed to different chemical substances, such as nicotine and azadirachtin, used as biopesticides.

Zaoralova et al. (2020) observed that the species Metrioptera roeselii (Hagenbach, 1822) (Tettigoniidae) and Chorthippus parallelus (Zetterstedt, 1821) (Acrididae) are bioaccumulators of toxic elements, highlighting that the Order Orthoptera is an appropriate group to study bioaccumulation. These insects can be contaminated by feeding, as most are herbivores (Mogren \& Trumble, 2010). Therefore, they act in the biotransfer and bioaccumulation of compounds, which are transported to the organs, where they are stored or metabolized (Devkota \& Schmidt, 2000). Thus, in the midgut lumen of herbivorous insects (and not in the tissues), the allelochemicals ingested find oxidation or reduction conditions for the first time (Felton et al., 1989; Appel, 1994; Barbehenn et al., 2001). From this perspective, the evaluation of antioxidant system enzymes constitutes an important component for herbivorous insects in their defense against exogenous and endogenous oxidative radicals.

Abracris flavolineata (De Geer, 1773) belongs to the Order Orthoptera (Acrididae: Ommatolampidinae) (Cigliano et al., 2020) and is widely distributed across the Neotropical region in countries such as Argentina, Mexico, and Brazil (Lhano, 2021). Its main habitat consists of open environments and forest edges (Roberts \& Carbonell, 1981), with a preference for moist forests (Rowell \& Behrstock 2012), being found in the middle strata of trees, bushes, and young trees (Costa et al. 2010). Due to its occurrence in the Serra da Jiboia region (BA), the few studies related to the activity of biochemical biomarkers in grasshoppers, and the absence of these data for the studied species, this study aimed to quantify the activity of the GST and CAT enzymes in A. flavolineata from forest remnant areas in Serra da Jiboia (BA) by comparing the enzyme activity between males and females and relating the responses of these biomarkers with the level of degradation of the sampling sites in order to assess the bioindicator potential of the species.

\section{Methodology}

\subsection{Study area}

The specimens of A. flavolineata were collected at two sampling sites in Serra da Jiboia, South Recôncavo region of Bahia, in the northern central corridor of the Atlantic Forest: Baixa de Areia (BA) (12 $\left.54^{\prime} 04.60^{\prime \prime} \mathrm{S} 39^{\circ} 28^{\prime} 26.23^{\prime \prime} \mathrm{W}\right)$ and Baixa Grande (BG) (1257'40.10”S 39²6'54.36”'W) (Figure 1).

Serra da Jiboia is an Atlantic Forest remnant composed of different conservation levels, with the presence of agricultural activities throughout its entire extent (Blengini et al., 2015). Although the largest part (65.4\%) of its extension is preserved, $34.6 \%$ of this hotspot is in early and middle regeneration stages or has disappeared (Caiafa, 2015). 
Figure 1. Sampling sites of Abracris flavolineata (De Geer, 1773) in Serra da Jiboia, Bahia, Brazil. The dashed line shows the distance $(\mathrm{km})$ between the sites. Sampled areas: Varzedo (Baixa de Areia = P1) and Elisio Medrado (Baixa Grande $=$ P2).

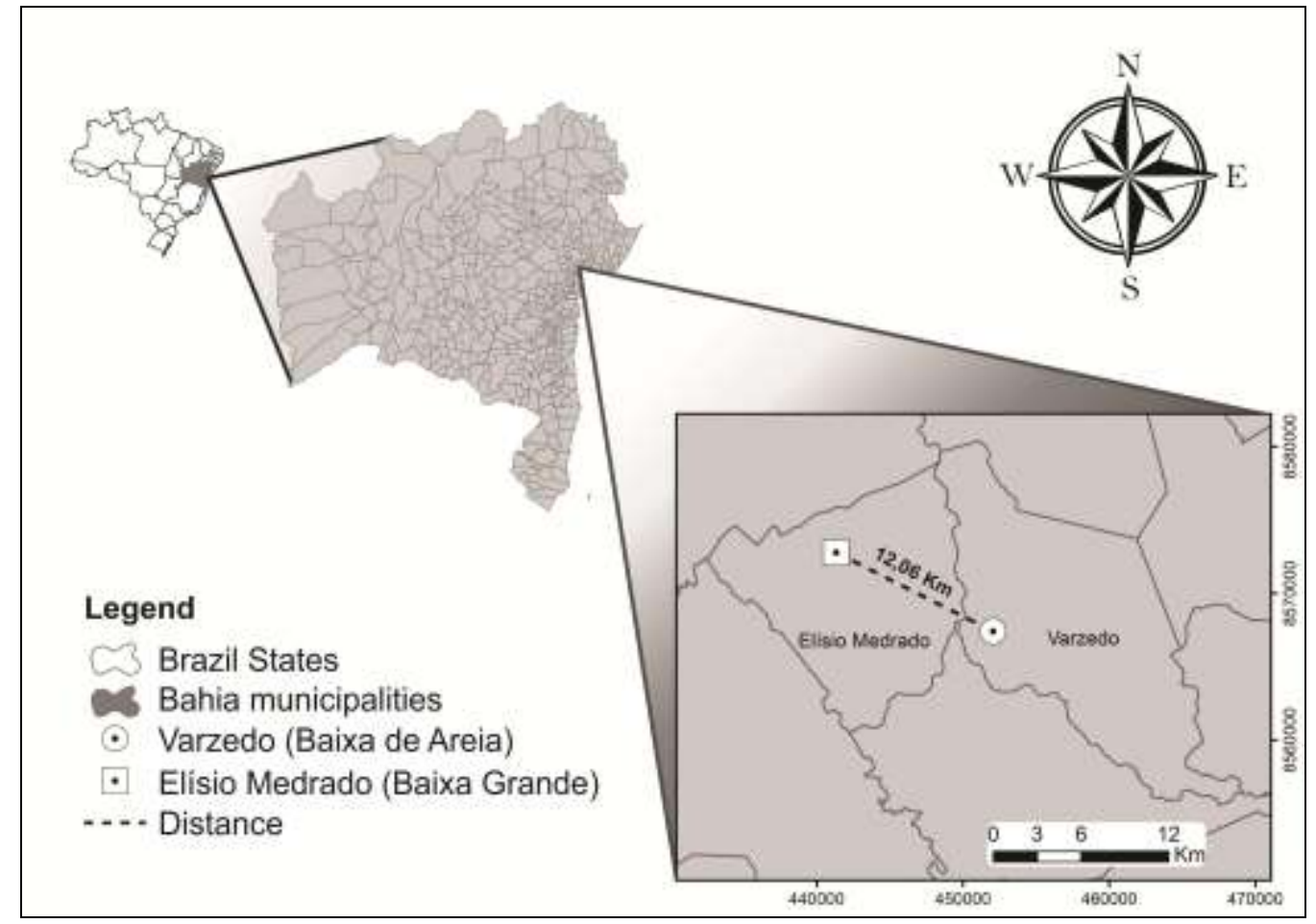

Source: Authors.

\section{Sampled areas}

P1 - Baixa de Areia (12 ${ }^{\circ} 54^{\prime} 04.60^{\prime}$ S 39 $\left.28^{\prime} 26.23^{\prime \prime} \mathrm{W}\right)$ : located east of the municipality of Varzedo (Bahia). Characterized by an Atlantic Ombrophilous Dense Forest vegetation (Caiafa, 2015) whose edge is rich in grasslands that serve as feed for cattle and fruit trees distributed across the property, such as cashew Anacardium occidentale (Anacardiaceae), jackfruit Artocarpus heterophyllus (Moraceae), mango Mangifera indica (Anarcadiaceae), and jenipapo Genipa americana (Rubiaceae). The area is located close to Highway BA-026, which connects the municipalities that compose the Serra da Jiboia. In addition to the traffic flow, the area is surrounded by crops such as banana (Musa spp. L. - Musaceae), cocoa (Theobroma cacao L. - Malvaceae), and cassava (Manihot esculenta Crantz - Euphorbiaceae), in addition to intensive cattle farming.

P2 - Baixa Grande (12 $\left.57^{\prime} 40.10^{\prime \prime S} 39^{\circ} 26^{\prime} 54.36^{\prime \prime W}\right)$ : located southeast of Serra da Jiboia, in the municipality of Elísio Medrado (BA). The area shows an Atlantic Ombrophilous Dense Forest vegetation and is located close to a rocky outcrop (Caiafa, 2015) characterized by its hard-to-reach location and the absence of a continuous traffic flow. Despite this, the area is surrounded by farming areas with crops such as banana and cocoa, in addition to grazing areas.

\subsection{Sampling}

The specimens of A. flavolineata were collected monthly in the two study areas from December 2016 to August 2017. The grasshoppers were captured in the morning by active sampling using a sweep net and a $2.5 \mathrm{~h}$ sampling effort by three collectors distant approximately five meters from each other.

The captured grasshoppers were individually transferred to plastic bags containing the vegetation of the sampling site in order to avoid stress and were subsequently stored in a thermal box. After sampling, the animals were transported to the Laboratory of Insect Ecology and Taxonomy (LETI) of CCAAB/UFRB for sex identification and species confirmation. 
Eighty specimens were collected at each sampling site (50 males and 30 females), totaling 160 individuals (100 males and 60 females).

\subsection{Sampling of the biological material}

After sex sorting, the animals were transferred to a plastic box containing ice until their metabolic activity was visibly reduced. Subsequently, using surgical material and a stereomicroscope (Olympus SZ51®, SZ2-ILST), an incision was made in the lateral region of the abdomen to remove the midgut. The midguts (IM) were immediately transferred to $1.5 \mathrm{~mL}$ cryotubes (Eppendorf ${ }^{\circledR}$ ), identified, and stored in an ultra-freezer (Sanyo ${ }^{\circ}$, Ultra Low) at $-80{ }^{\circ} \mathrm{C}$ to determine the activity of the CAT and GST enzymes.

Due to the reduced size of the biological material, each sample was composed of 'pools', using five midguts for males and three for females. Thus, ten samples were analyzed for each sex and sampling site.

\subsection{Biochemical biomarkers}

The frozen sample pool was homogenized in phosphate buffer solution ( $\mathrm{pH}$ 6.8) in a proportion of 1:10 (weight:volume) in an ice-cooled container. Subsequently, the homogenized material was centrifuged at 10,000 RPM for 20 minutes in a centrifuge (Hettich®, MIKRO 220R) refrigerated at $4^{\circ} \mathrm{C}$. After centrifugation, the supernatant was separated with the aid of a micropipette and transferred to previously identified cryotubes. The samples were stored in an ultra-freezer at - 80 ${ }^{\circ} \mathrm{C}$ for later determination of the activity of the CAT and GST enzymes.

CAT activity ( $\mathrm{nmol} \mathrm{H}_{2} \mathrm{O}_{2} \mathrm{~min}^{-1} \mathrm{mg} \cdot \mathrm{pt}^{-1}$ ) was determined based on the degradation of exogenous $\mathrm{H}_{2} \mathrm{O}_{2}$, generating $\mathrm{H}_{2} \mathrm{O}$ and $\mathrm{O}_{2}$ as byproducts (Aebi, 1984). The readings were performed in triplicate with a UV/Vis spectrophotometer (Biochrom Libra®, S21/ S22) (software Reaction kinetics), using quartz cuvettes and a 240 nm wavelength. GST activity (nmol CDNB $\min ^{-1} \mathrm{mg} \mathrm{pt}^{-1}$ ) was determined based on the catalyzation of the conjugation reaction of the substrate 1-26 chloro2,4-dinitrobenzene (CDNB) with reduced glutathione at a wavelength of $340 \mathrm{~nm}$ in acrylic cuvettes (Keen et al., 1976). The total liver protein concentration was quantified using a commercial kit (Interkitß).

\subsection{Statistical analyses}

In our work, we used the experimental method of a quantitative nature (Pereira et al., 2018), with the analysis of the mean and standard deviation values of the analyzed biomarkers. The CAT and GST activity results were expressed using the mean and standard deviation of the samples, and the mean values of the analyzed parameters were compared using a two-way analysis of variance (ANOVA). When significant differences were identified ( $<<0.05$ ), the Tukey test was applied at 5\% significance to compare the means. All analyses were performed with the statistical software Statistica, version 7.0.

\section{Results}

By comparing the results obtained, catalase (CAT) activity did not vary significantly between sampling sites and in the interaction between sex and sampling sites (Table 1). However, CAT activity was significantly higher in males (p<0.05) than in females in both sites (Figure 2). 
Table 1. ANOVA for catalase enzyme activity in Abracris flavolineata (De Geer, 1773) collected at the Baixa de Areia and Baixa Grande sites, Serra da Jiboia, Bahia.

\begin{tabular}{lccccc}
\hline & SQ & GL & QM & F & P \\
\hline Sampling site & 0.8 & 1 & 0.8 & 0.0009 & $0.976095^{\text {ns }}$ \\
Sex & 10120.4 & 1 & 10120.4 & 11.9933 & $\mathbf{0 . 0 0 1 3 9 5 *}^{*}$ \\
Sampling site x Sex & 589.4 & 1 & 589.4 & 0.6985 & $0.408808^{\text {ns }}$ \\
\hline Error & 30378.1 & 36 & 843.8 & & \\
\hline
\end{tabular}

ns Non-significant; *significant $(\mathrm{p}<0.05)$; Sum of squares (SQ); Degree of freedom (GL); Mean square (QM); F (Variance ratio); P (Significance probability). Source: Authors.

Figure 2. Mean values of catalase activity in females and males of Abracris flavolineata (De Geer, 1773) collected at the Baixa de Areia and Baixa Grande sites, Serra da Jiboia (BA). Values shown as mean \pm standard deviation. Means followed by the same letter do not differ by the Tukey test at $5 \%$ probability; lowercase letters represent the comparison between sexes, and uppercase letters represent the sampling sites.

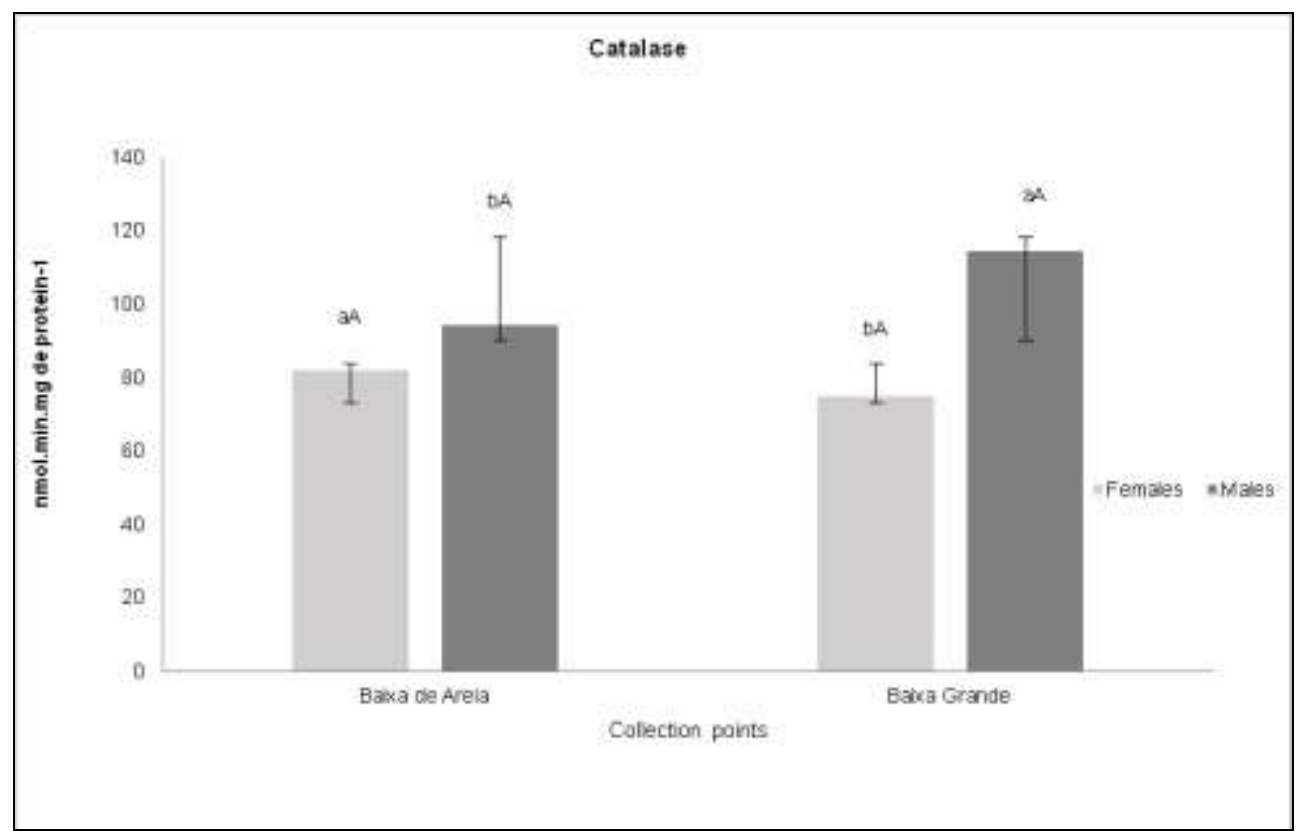

Source: Authors.

The enzymatic activity of glutathione S-transferase (GST) in males and females of A. flavolineata did not differ between sampling sites (ANOVA p>0.05). However, a significant difference in the activity was observed between sexes and in the interaction between sex and sampling sites $(\mathrm{p}<0.05)$, as observed in the data shown in Table 2. 
Table 2. ANOVA for glutathione S-transferase enzyme activity in Abracris flavolineata (De Geer, 1773) collected at the Baixa de Areia and Baixa Grande sites, Serra da Jiboia, Bahia.

\begin{tabular}{lccccc}
\hline & SQ & GL & QM & F & P \\
\hline Sampling site & 687 & 1 & 687 & 0.3548 & $0.555121^{\mathrm{ns}}$ \\
Sex & 67126 & 1 & 67126 & 34.6747 & $\mathbf{0 . 0 0 0 0 0 1 *}$ \\
Sampling site x Sex & 14050 & 1 & 14050 & 7.2578 & $\mathbf{0 . 0 1 0 6 5 5 ^ { * }}$ \\
\hline Error & 69692 & 36 & 1936 & & \\
\hline
\end{tabular}

ns Non-significant; *significant ( $<<0.05$ ); Sum of squares (SQ); Degree of freedom (GL); Mean square (QM); F (Variance ratio); P (Significance probability). Source: Authors.

Similar to CAT, GST activity was also higher in the males of A. flavolineata compared to females (Figure 3). This result was observed in the animals from both sampling sites (Baixa de Areia and Baixa Grande) at Serra da Jiboia (Bahia).

Figure 3. Mean values of glutathione S-transferase activity in females and males of Abracris flavolineata (De Geer, 1773) collected at the Baixa de Areia (BA) and Baixa Grande (BG) sites, Serra da Jiboia, (BA). Values shown as mean \pm standard deviation. Means followed by the same letter do not differ by the Tukey test at $5 \%$ probability; lowercase letters represent the comparison between sexes, and uppercase letters represent the sampling sites.

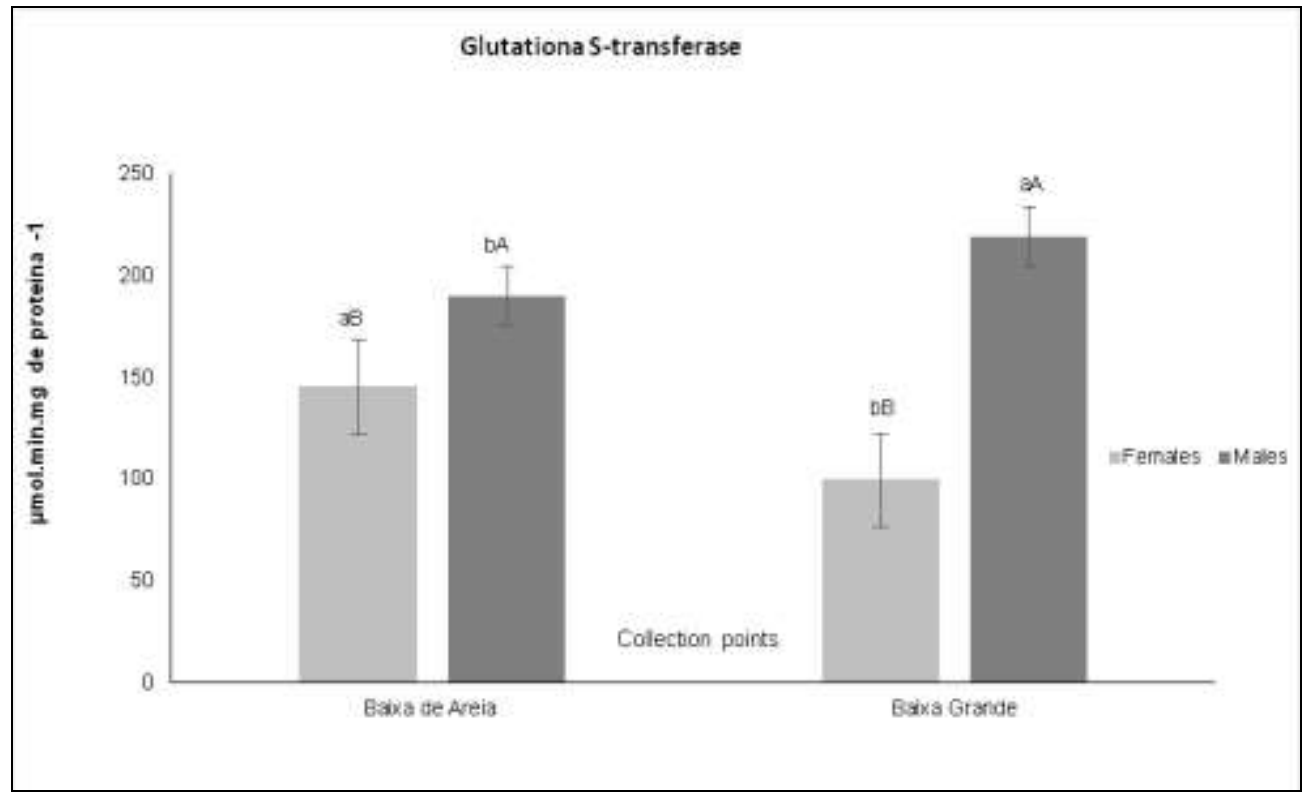

Source: Authors.

\section{Discussion}

Since they act in the protection mechanism against oxidative stress in several organisms, including insects, the response of catalase and glutathione S-transferase activity (Pavlidi et al., 2018) can be used as a bioindicator of environmental contamination. However, few studies have characterized the activity of these biomarkers in grasshoppers. Therefore, this is a pioneer study for the species as well as for grasshoppers in Latin America.

The enzyme catalase (CAT) is present in both aerobic and anaerobic organisms, and its function is to decrease the toxicity of hydrogen peroxide. In addition to detoxification, glutathione S-transferase (GST) also acts in the process of biotransformation, decreasing the toxicity of xenobiotics to the cell (Benavides et al., 2016). Thus, both enzymes are involved 
in the defense against Reactive Oxygen Species (ROS), and their responses have been used to assess the exposure effects of various insect species to different chemical compounds (Wilczek et al., 2008; Wilczek et al., 2013; Zhang et al., 2011; Nwaubani et al., 2015).

In our study, a higher CAT and GST activity was observed in the males of A. flavolineata than in females. In turn, Augustyniak \& Migula (2000) observed higher CAT activity in the midgut of females of Chorthippus brunneus (Thunberg, 1815) (Acrididae, Gomphocerinae, Gomphocerini) collected in Poland. However, the same authors mention that GST activity was higher in males, corroborating our results for this enzyme. Wilczek et al. (2013) observed a similar result in spiders $(X$. nemoralis) collected at two different locations in southern Poland. The authors observed higher CAT activity in females than in males. However, the activity of the GST enzyme was also higher in the midgut of males. These data highlight the importance of sex identification to analyze these biomarkers as enzyme activity may vary between males and females of the same species.

The variation in CAT and GST activity as a function of sex has also been observed in other arthropods, such as in the spiders Linyphia triangularis (Clerck, 1757) (Linyphiidae) and Xerolycosa nemoralis (Westring, 1861) (Lycosidae) collected at two locations in southern Poland (Wilczek et al. 2008). In the study by Wilczek et al. 2008, CAT and GST activity was also observed in males. According to the authors, males may be more sensitive to oxidative stress than females (Wilczek et al., 2008). Thus, the higher CAT and GST activity observed in A. flavolineata may be related to the sensitivity of male animals to a stressor present in the environment. The rapid response of these biomarkers may suggest that males are more protected as they readily activate defense mechanisms that protect them from the negative effects of oxidative stress (Wilczek et al., 2013).

Individuals of different sexes of the same species can use different metabolic pathways to attempt to reduce the oxidative stress caused by the presence of ROS. Thus, the activity of an enzyme can reduce or compensate for the activity of another. CAT activation can be compensated by the higher activity of glutathione peroxidase (GSH), superoxide dismutase (SOD), and glutathione reductase (GR) (Felton \& Summers, 1995; Wang et al., 2001). The activity of these antioxidant enzymes can be increased or inhibited under chemical stress, suggesting that there is no general rule for their activity (Hou et al., 2019).

Zhang et al. (2011) observed the effect of different cadmium (Cd) concentrations $\left(0.2,0.4\right.$, and $\left.0.8 \mathrm{mmol} \mathrm{L}^{-1}\right)$ on CAT activity at different developmental stages of Oxya chinensis grasshoppers (Thunberg, 1815) (Acrididae, Oxyinae, Oxyini). The authors observed an increase in CAT activity with increased exposure to $\mathrm{Cd}$. Thus, in addition to sex, insect exposure to a contaminant may interfere with the results of this enzyme. In another study, Lijun et al. (2005) also observed a significant correlation between increased CAT activity and increased exposure to $\mathrm{Cd}$ in males and females of Oxya chinensis Thunberg, 1815 (Acrididae).

Coleoptera specimens of Pterostichus oblongopunctatus (Fabricius, 1787) (Carabidae), Geotrupes stercorosus (Scriba, 1791) (Geotrupidae), Staphylinus caesareus (Cederhjelm, 1798) (Staphylinidae), and Phyllobius betulae (Fabricius, 1801) (Curculionidae) collected from areas contaminated with heavy metals ( $\mathrm{Pb}, \mathrm{Zn}, \mathrm{Cd}, \mathrm{Cu}$ ) in Poland also showed variation in the values of CAT and GST activity. Therefore, the response pattern of the activity of these enzymes can be used as an indicator of toxic elements in the environment (Migula et al., 2004).

In our study, despite the significant differences with regard to the anthropization of the sampling sites of $A$. flavolineata, CAT and GST activity did not vary significantly between the Baixa de Areia and Baixa Grande sites. Therefore, it was not possible to characterize the most impacted location based on the response of the analyzed biomarkers. In both sampling sites, it was possible to observe the cultivation of species such as banana, cocoa, and cassava, in addition to a grazing area. According to Blengini et al. (2015), the use of chemical products to control agricultural pests is a common practice in the region. However, it was not possible to relate the agricultural activity of the sampling sites with the CAT and GST responses. 
A probable explanation is the resistance that the studied species may have developed to the pesticides by natural selection (Brahimi et al., 2020). This resistance mechanism involves nonspecific enzymes that normally detoxify toxins and include monooxygenases, oxidases, antioxidases, hydrolases, and transferases (Roy et al., 2016; Birnbaum et al., 2017). Toxin-exposed insects may have higher levels of more efficient forms of these enzymes to induce tolerance (Després et al., 2007; Tangtrakulwanich \& Reddy, 2014), such as detoxifying (including cytochrome P450s, UDP-glucuronosyltransferase, carboxylesterase, and glutathione S-transferase) and antioxidant enzymes (including superoxide dismutase, catalase, and peroxidase), which are activated after exposure to toxins (Mittapalli et al., 2007; Birnbaum et al., 2017; Wang et al., 2018).

Nwaubani et al. (2015) also found no significant difference in the activity of the CAT, GSH, GST, and SOD enzymes in dragonflies Austroaeschna inermis Martin, 1901 (Odonata: Aeshnidae) collected at different locations in Nigeria. On the other hand, Yousef et al. (2017) observed a variation in the CAT activity of grasshoppers Aiolopus thalassinus (Fabricius, 1781) (Acrididae, Oedipodinae, Epacromiini) from areas polluted by the fertilizer industry. Thus, according to the authors, the exposure to contaminants present in the environment may be related to higher CAT activity, as observed in grasshoppers from that area.

Barbehenn (2002) also observed high CAT activity in the grasshoppers Melanoplus sanguinipes (Fabricius, 1798) and Aulocara elliotti (C.Thomas, 1870) of the family Acrididae after ingesting plants contaminated with tannic acid. In the same study, CAT activity was higher in M. sanguinipes, suggesting the existence of intraspecific sensitivity.

Therefore, although it was not possible to use the responses of CAT and GST activity in Abracris flavolineata to separate the sampling sites studied, the activity of these enzymes can be used in future studies with other populations as the species has a wide distribution. Finally, it is worth noting that the Order Orthoptera is an appropriate group to study bioaccumulation (Zaoralova et al., 2020), and the results obtained here can contribute to environmental biomonitoring.

\section{Conclusion}

Our study allowed identifying and quantifying the activity of the enzymes catalase and glutathione S-transferase (GST) from the midguts of grasshoppers Abracris flavolineata. The responses of these biomarkers were not sufficient to characterize the sampling sites studied with regard to the presence of contaminants, which is probably due to the similarity between locations and the proximity of the populations. We highlight the higher CAT and GST activity in males of Abracris flavolineata compared to females. Thus, our results can be used as a reference for future research as this is a pioneer ecotoxicological study with grasshoppers in Brazil.

\section{Acknowledgments}

We thank the Federal University of Recôncavo da Bahia (UFRB) for providing the facilities. This study was financed in part by the Coordination for the Improvement of Higher Education Personnel - Brazil (CAPES) - Finance Code 001.

\section{References}

Aebi, H. (1984). [13] Catalase in vitro. Methods in Enzymology, 105, 121-126. https://doi.org/10.1016/s0076-6879(84)05016-3

Afiyanti, M., \& Chen, H. J. (2014). Catalase activity is modulated by calcium and calmodulin in detached mature leaves of sweet potato. Journal of Plant Physiology, 171(2), 35-47. https://doi.org/10.1016/j.jplph.2013.10.003

Ahmad, S. (1992). Biochemical defence of pro-oxidant plant allelochemicals by herbivorous insects. Biochemical Systematics and Ecology, 20(4), 269-296. https://doi.org/10.1016/0305-1978(92)90040-k

Appel, H. M. (2017). [Chapter 7] The chewing herbivore gut lumen: physicochemical conditions and their impact on plant nutrients, allelochemicals, and insect pathogens. In Insect-Plant Interactions - Volume V (pp. 209-224). CRC Press. https://doi.org/10.1201/9780203711651

Augustyniak, M., \& Migula, P. (2000). [Chapter 16] Body burden with metals and detoxifying abilities of the grasshopper — Chorthippus brunneus 
(Thunberg) from industrially polluted areas. Trace Elements - Their Distribution and Effects in the Environment, 4, 423-454. https://doi.org/10.1016/s0927$5215(00) 80019-3$

Augustyniak, M., Orzechowska, H., Kędziorski, A., Sawczyn, T., \& Doleżych, B. (2014). DNA damage in grasshoppers' larvae - Comet assay in environmental approach. Chemosphere, 96, 180-187. https://doi.org/10.1016/j.chemosphere.2013.10.033

Barbehenn, R. V. (2002). Gut-based antioxidant enzymes in a polyphagous and a graminivorous grasshopper. Journal of Chemical Ecology, 28(7), 13291347. https://doi.org/10.1023/a:1016288201110

Barbehenn, R. V. (2003). Antioxidants in grasshoppers: higher levels defend the midgut tissues of a polyphagous species than a graminivorous species. Journal of Chemical Ecology, 29(3), 683-702. https://doi.org/10.1023/a:1022824820855

Barbehenn, R. V., Bumgarner, S. L., Roosen, E. F., \& Martin, M. M. (2001). Antioxidant defenses in caterpillars: role of the ascorbate-recycling system in the midgut lumen. Journal of Insect Physiology, 47(4-5), 349-357. https://doi.org/10.1016/s0022-1910(00)00125-6erratum:47:1095

Benavides, M., Fernández-Lodeiro, J., Coelho, P., Lodeiro, C., \& Diniz, M. S. (2016). Single and combined effects of Aluminum (Al2O3) and Zinc (ZnO) oxide nanoparticles in a freshwater fish, Carassius auratus. Environmental Science and Pollution Research, 23(24), 24578-24591. https://doi.org/10.1007/s11356-016-7915-3

Birben, E., Sahiner, U. M., Sackesen, C., Erzurum, S., \& Kalayci, O. (2012). Oxidative stress and antioxidant defense. World Allergy Organization Journal, 5(1), 9-19. https://doi.org/10.1097/wox.0b013e3182439613

Birnbaum, S. S. L., Rinker, D. C., Gerardo, N. M., \& Abbot, P. (2017). Transcriptional profile and differential fitness in a specialist milkweed insect across host plants varying in toxicity. Molecular Ecology, 26(23), 6742-6761. https://doi.org/10.1111/mec.14401

Blengini, I. A. D., Cintra, M. A. M. de U., Cunha, R. P. P. da, \& Caiafa, A. N. (Eds.). (2015). Proposta de Unidade de Conservação da Serra da Jiboia (p. 230). Grupo Ambientalista da Bahia (Gambá) / Universidade Federal do Recôncavo da Bahia (UFRB). http://www.gamba.org.br/wpcontent/uploads/2016/03/Proposta-Final.pdf

Board, P. G., \& Menon, D. (2013). Glutathione transferases, regulators of cellular metabolism and physiology. Biochimica et Biophysica Acta (BBA) - General Subjects, 1830(5), 3267-3288. https://doi.org/10.1016/j.bbagen.2012.11.019

Brahimi, D., Mesli, L., Rahmouni, A., Zeggai, F. Z., Khaldoun, B., Chebout, R., \& Belbachir, M. (2020). Why Orthoptera fauna resist of pesticide? First experimental data of resistance phenomena. Data in Brief, 30, 105659. https://doi.org/10.1016/j.dib.2020.105659

Caiafa, A. N. (2015). A Vegetação na Serra da Jiboia. In I. A. D. Blengini, M. A. M. de U. Cintra, R. P. P. da Cunha, \& A. N. Caiafa (Eds.), Proposta de Unidade de Conservação da Serra da Jiboia (pp. 72-83). Grupo Ambientalista da Bahia (Gambá).

Cigliano, M. M., Braun, H., Eades, D. C., \& Otte, D. (1987, January 21). Homepage: Orthoptera Species File. Version 5.0/5.0. Orthoptera.speciesfile.org; Orthopterists' Society. http://Orthoptera.SpeciesFile.org

Costa, M. K. M. da, Carvalho, G. S., \& Fontanetti, C. S. (2010). Cladistic analysis of Abracrini genera (Orthoptera, Acrididae, Ommatolampinae). Zootaxa, 2451(1), 1-25. https://doi.org/10.11646/zootaxa.2451.1.1

Després, L., David, J.-P., \& Gallet, C. (2007). The evolutionary ecology of insect resistance to plant chemicals. Trends in Ecology \& Evolution, 22(6), 298307. https://doi.org/10.1016/j.tree.2007.02.010

Devkota, B., \& Schmidt, G. H. (2000). Accumulation of heavy metals in food plants and grasshoppers from the Taigetos Mountains, Greece. Agriculture, Ecosystems \& Environment, 78(1), 85-91. https://doi.org/10.1016/s0167-8809(99)00110-3

Felton, G. W., Donato, K., Del Vecchio, R. J., \& Duffey, S. S. (1989). Activation of plant foliar oxidases by insect feeding reduces nutritive quality of foliage for noctuid herbivores. Journal of Chemical Ecology, 15(12), 2667-2694. https://doi.org/10.1007/bf01014725

Felton, G. W., \& Summers, C. B. (1995). Antioxidant systems in insects. Archives of Insect Biochemistry and Physiology, 29(2), 187-197. https://doi.org/10.1002/arch.940290208

Hou, J., Wang, L., Wang, C., Zhang, S., Liu, H., Li, S., \& Wang, X. (2019). Toxicity and mechanisms of action of titanium dioxide nanoparticles in living organisms. Journal of Environmental Sciences, 75, 40-53. https://doi.org/10.1016/j.jes.2018.06.010

Hsu, M. J., Selvaraj, K., \& Agoramoorthy, G. (2006). Taiwan's industrial heavy metal pollution threatens terrestrial biota. Environmental Pollution, 143(2), 327-334. https://doi.org/10.1016/j.envpol.2005.11.023

Kafel, A., Rozpędek, K., Szulińska, E., Zawisza-Raszka, A., \& Migula, P. (2014). The effects of cadmium or zinc multigenerational exposure on metal tolerance of Spodoptera exigua (Lepidoptera: Noctuidae). Environmental Science and Pollution Research, 21(6), 4705-4715. https://doi.org/10.1007/s11356$013-2409-\mathrm{z}$

Keen, J. H., Habig, W. H., \& Jakoby, W. B. (1976). Mechanism for the several activities of the Glutathione S-Transferases. The Journal of Biological Chemistry, 251(20), 6183-6188.

Lhano, M. G. (2021). Orthoptera. Catálogo Taxonômico da Fauna do Brasil (CTFB); PNUD. http://fauna.jbrj.gov.br/fauna/faunadobrasil/294

Lijun, L., Xuemei, L., Yaping, G., \& Enbo, M. (2005). Activity of the enzymes of the antioxidative system in cadmium-treated Oxya chinensis (Orthoptera Acridoidae). Environmental Toxicology and Pharmacology, 20(3), 412-416. https://doi.org/10.1016/j.etap.2005.04.001

Lushchak, V. I. (2011). Environmentally induced oxidative stress in aquatic animals. Aquatic Toxicology, 101(1), 13-30. https://doi.org/10.1016/j.aquatox.2010.10.006 
Migula, P., Łaszczyca, P., Augustyniak, M., Wilczek, G., Rozpędek, K., Kafel, A., \& Wołoszyn, M. (2004). Antioxidative defence enzymes in beetles from a metal pollution gradient. Biologia - Section Zoology, Bratislava, 59(5), 645-654.

Mittapalli, O., Neal, J. J., \& Shukle, R. H. (2007). Antioxidant defense response in a galling insect. Proceedings of the National Academy of Sciences, 104(6), 1889-1894. https://doi.org/10.1073/pnas.0604722104

Mogren, C. L., \& Trumble, J. T. (2010). The impacts of metals and metalloids on insect behavior. Entomologia Experimentalis et Applicata, 135(1), 1-17. https://doi.org/10.1111/j.1570-7458.2010.00967.x

Mota, T. A., Winkaler, E. U., Oliveira, G. de \& Rocha, S. S. da. (2021). Enzymatic response of Macrobrachium jelskii (Miers, 1877) exposed to water from urban and rural rivers in Bahia, Brazil. Research, Society And Development, 10(6). https://doi.org/10.33448/rsd-v10i6.15638

Nwaubani, B. I., Amaeze, N. H., \& Idowu, E. T. (2015). Heavy metal bioaccumulation and oxidative stress in Austroaeschna inermis (Dragon fly) of the Lagos Urban ecosystem. Journal of Environmental Chemistry and Ecotoxicology, 7(1), 11-19. https://doi.org/10.5897/jece2014.0336

Paital, B. (2018). Removing small non-enzymatic molecules for biochemical assay of redox regulatory enzymes; An exemplary comments on "Antioxidant responses in gills and digestive gland of oyster Crassostrea madrasensis (Preston) under lead exposure. Ecotoxicology and Environmental Safety, 154, 337340. https://doi.org/10.1016/j.ecoenv.2018.01.051

Pavlidi, N., Vontas, J., \& Van Leeuwen, T. (2018). The role of glutathione S-transferases (GSTs) in insecticide resistance in crop pests and disease vectors. Current Opinion in Insect Science, 27, 97-102. https://doi.org/10.1016/j.cois.2018.04.007

Pereira, A. S., Shitsuka, D. M., Parreira, F. J. \& Shitsuka, R. (2018). Metodologia da Pesquisa Científica. [free e-book]. Santa Maria: RS. Ed. UAB/NTE/UFSM.

Pierezan, B., Webber, B., Vidmar, M. F., Martins, C. A. de Q., Almeida, C. R. de, \& Siqueira, L. de O. (2017). Análise do perfil oxidativo de diferentes amostras biológicas de pacientes com lesão de ligamento cruzado anterior. Fisioterapia E Pesquisa, 24(2), 198-204. https://doi.org/10.1590/18092950/17409924022017

Roberts, H. R., \& Carbonell, C. S. (1981). A revision of the Neotropical genus Abracris and related genera (Orthoptera, Acrididae, Ommatolampinae). Proceedings of the Academy of Natural Sciences of Philadelphia, 133, 1-14.

Rowell, C. H. F., \& Behrstock, R. A. (2012). Additions to the acridoid grasshopper fauna of El Salvador. Journal of Orthoptera Research, 21(2), 235-243. https://doi.org/10.1665/034.021.0208

Roy, A., Walker, W. B., Vogel, H., Chattington, S., Larsson, M. C., Anderson, P., Heckel, D. G., \& Schlyter, F. (2016). Diet dependent metabolic responses in three generalist insect herbivores Spodoptera spp. Insect Biochemistry and Molecular Biology, 71, 91-105. https://doi.org/10.1016/j.ibmb.2016.02.006

Tangtrakulwanich, K., \& Reddy, G. V. P. (2014). Development of insect resistance to plant biopesticides: an overview. In Advances in Plant Biopesticides (pp. 47-62). Springer. https://doi.org/10.1007/978-81-322-2006-0_4

Valavanidis, A., Vlahogianni, T., Dassenakis, M., \& Scoullos, M. (2006). Molecular biomarkers of oxidative stress in aquatic organisms in relation to toxic environmental pollutants. Ecotoxicology and Environmental Safety, 64(2), 178-189. https://doi.org/10.1016/j.ecoenv.2005.03.013

Wang, R.-L., Liu, S.-W., Baerson, S., Qin, Z., Ma, Z.-H., Su, Y.-J., \& Zhang, J.-E. (2018). Identification and functional analysis of a novel cytochrome P450 gene CYP9A105 associated with pyrethroid detoxification in Spodoptera exigua Hübner. International Journal of Molecular Sciences, $19(3)$, 737. https://doi.org/10.3390/ijms19030737

Wang, Y., Huang, X., Chang, B. H., \& Zhang, Z. (2020). Growth performance and enzymatic response of the grasshopper, Calliptamus abbreviatus (Orthoptera: Acrididae), to six plant-derived compounds. Journal of Insect Science, 20(3), 14. https://doi.org/10.1093/jisesa/ieaa049

Wang, Y., Oberley, L. W., \& Murhammer, D. W. (2001). Antioxidant defense systems of two lipidopteran insect cell lines. Free Radical Biology and Medicine, 30(11), 1254-1262. https://doi.org/10.1016/s0891-5849(01)00520-2

Wilczek, G., Babczyńska, A., \& Wilczek, P. (2013). Antioxidative responses in females and males of the spider Xerolycosa nemoralis (Lycosidae) exposed to natural and anthropogenic stressors. Comparative Biochemistry and Physiology Part C: Toxicology \& Pharmacology, 157(2), 119-131. https://doi.org/10.1016/j.cbpc.2012.10.005

Wilczek, G., Babczyńska, A., Wilczek, P., Doleżych, B., Migula, P., \& Młyńska, H. (2008). Cellular stress reactions assessed by gender and species in spiders from areas variously polluted with heavy metals. Ecotoxicology and Environmental Safety, 70(1), 127-137. https://doi.org/10.1016/j.ecoenv.2007.03.005

Yousef, H. A., Abdelfattah, E. A., \& Augustyniak, M. (2017). Evaluation of oxidative stress biomarkers in Aiolopus thalassinus (Orthoptera: Acrididae) collected from areas polluted by the fertilizer industry. Ecotoxicology, 26(3), 340-350. https://doi.org/10.1007/s10646-017-1767-6

Zaoralova, Z., Kupka, J., \& Stalmachova, B. (2020). Orthoptera insects as bioaccumulators of potentially toxic elements (Ostrava city, Czech Republic). IOP Conference Series: Earth and Environmental Science, 444, 012057. https://doi.org/10.1088/1755-1315/444/1/012057

Zhang, Y., Sun, G., Yang, M., Wu, H., Zhang, J., Song, S., Ma, E., \& Guo, Y. (2011). Chronic accumulation of cadmium and its effects on antioxidant enzymes and malondialdehyde in Oxya chinensis (Orthoptera: Acridoidea). Ecotoxicology and Environmental Safety, 74(5), 1355-1362. https://doi.org/10.1016/j.ecoenv.2011.03.002 